\title{
КОРЕКЦІЯ ВІТАМІНАМИ ГРУПИ В ПОРУШЕНЬ ТРАНССУЛЬФУРАЗНОГО ШЛЯХУ УТИЛІЗАЦІЇ ГОМОЦИСТЕЇНУ ПРИ ГІПЕР- І ГІПОФУНКЦІЇ ЩИТОПОДІБНОї ЗАЛОЗИ
}

Вступ. Дисфуннція щитоподібної залози - фрактор розвитку багатьох серцево-судинних захворювань, водночас гіпергомоцистеїнемія також є добре відомим чинником розвитку патологій серцево-судинної системи. Встановлено, що експериментальний гіпертиреоз викликає зменшення рівня гомоцистеїну (ГЦ) у крові, водночас гіпотиреоз призводить до протилежних змін в обміні сірковмісних амінокислот, зокрема, підвищується вміст ГЦ у крові, знижується рівень $\mathrm{H}_{2} \mathrm{~S}$ і зростає рівень цистеїну, що є наслідком змін активності ензимів метаболізму метіоніну.

Мета дослідження - з'ясувати вплив гормонів щитоподібної залози на процеси транссульфування ГЦ в органах тварин, оцінити можливість корекції порушених під впливом гіпер- та гіпотиреозу процесів обміну ГЦ за допомогою вітамінів $B_{6}, B_{9}, B_{12}$ i бетаїну.

Meтоди дослідження. Роботу виконано на щурах-самцях, у яких досліджували вплив гіпер- (L-muроксин, 200 мкг/добу на 1 кг маси) та гіпотиреозу (мерказоліл, 10 мг/добу на 1 кг маси) на реакції транссульфування ГЦ в органах тварин і корекцію порушених під впливом L-тироксину та мерказолілу процесів обміну ГЦ за допомогою вітамінів $B_{6}, B_{9}, B_{12}$ i бетаїну. У печінці й нирках визначали цистатіонінсинтазну активність цистатіонін- $\beta$-синтази (ЦБС) і цистатіоніназну активність цистатіонін-у-ліази (ЦГЛ), у мозку - тільки активність ЦБС, у крові - вміст ГЦ та цистеїну.

Результати й обговорення. Гіпертиреоз викликав зростання цистатіонінсинтазної активності ЦБС у печінці та мозку. Застосування вітаміну $B_{6}$ у тварин з гіпертиреозом призводило до ще більшого підвищення цього показника. Цистатіоніназна активність ЦГЛ при гіпертиреозі й використанні вітаміну $B_{6}$ достовірно зростала лише в нирках. Бетаїн, $B_{9}$ ma $B_{12}$ у тварин з гіпертиреозом спричиняли підвищення активності ЦБС у мозку та печінці. Гіпертиреоз знижував рівень ГЦ та не впливав на рівень цистеїну. Фолієва кислота, ціанокобаламін, піридоксин і бетаїн, при їх введенні паралельно з L-тироксином, частково запобігали зменшенню концентрації ГЦ у крові. Мерказоліл пригнічував активність ензимів шляху транссульфрування порівняно з інтактними тваринами: ЦБС - у печінці та нирках, ЦГЛ - у нирках. Піридоксин частково попереджував зниження активності ЦБС у печінці та мозку, бетаїн - активності ЦБС у тканинах печінки, нирок і мозку й активності ЦГл лише в нирках. Найефективнішою виявилася комбінація вітамінів групи В і бетаїну. Гіпотиреоз призводив до підвищення вмісту в крові ГЦ і цистеїну. Вітаміни $B_{6}$, $B_{9}$ та $B_{12}$, а також комбінація всіх середників викликали у тварин з гіпотиреозом зниження рівня ГЦ.

Висновки. Тривалі гіпер- та гіпотиреоз викликають дисбаланс иляху транссульсрування ГЦ. Фолієва кислота, ціанокобаламін, піридоксин і бетаїн частково запобігають порушенню процесів метаболізму сірковмісних амінокислот та призводять до зниження рівня ГЦ і цистеїну в крові щурів з гіпотиреозом.

КЛЮЧОВІ СЛОВА: гіпертиреоз; гіпотиреоз; цикл транссульфування; гомоцистеїн; цистеїн; вітаміни $\mathrm{B}_{6}, \mathrm{~B}_{9}, \mathrm{~B}_{12}$; бетаїн.

ВСТУП. Гіпергомоцистеїнемія характеризується підвищеним рівнем токсичного гомоцистеїну (ГЦ) у плазмі. Його концентрація в плазмі здорових людей становить 5-15 мкмоль/л, тоді як у гіпергомоцистеїнемічних пацієнтів вона може досягати 500 мкмоль/л. Зростання рівня ГЦ може викликати такі стани, як остеопороз, ектопія кришталика, ниркова недостатність, (с) В. М. Нечипорук, М. М. Корда, 2020. нейродегенеративні хвороби (зокрема, хвороба Альцгеймера, хвороба Паркінсона та деменція), діабет, рак, синдром Дауна, мегалобластична анемія, проте найбільш тісно високий рівень ГЦ пов'язаний із серцево-судинними ускладненнями [1, 2].

Відомо, що гіпотиреоз може спричиняти значні метаболічні розлади та збільшувати ризик виникнення серцево-судинних захворювань [3]. 
Наші попередні дослідження показали, що експериментальний гіпертиреоз викликає зменшення рівня ГЦ у крові, водночас гіпотиреоз призводить до протилежних змін в обміні сірковмісних амінокислот, зокрема, підвищується вміст ГЦ у крові, знижується рівень $\mathrm{H}_{2} \mathrm{~S}$ і зростає рівень цистеїну, що $€$ наслідком змін активності ензимів метаболізму метіоніну [4]. На сьогодні залишається малодослідженим патогенетичний взаємозв'язок між рівнем ГЦ, цистеїну та фрункціональним станом щитоподібної залози.

Відомо, що функціонування циклу метилування ГЦ визначається забезпеченістю тканин організму вітамінами $\mathrm{B}_{9}, \mathrm{~B}_{12}$ i бетаїном, а для ензимів циклу транссульфування ГЦ (цистатіонін- $\beta$-синтази (ЦБС), цистатіонін-ү-ліази (ЦГЛ)) необхідний вітамін $\mathrm{B}_{6}$.

У цій роботі ми досліджували можливість корекції порушених під впливом L-тироксину та мерказолілу процесів обміну ГЦ за допомогою сролієвої кислоти, ціанокобаламіну, піридоксину і бетаїну.

Мета дослідження - з'ясувати вплив гормонів щитоподібної залози на процеси транссульсрування ГЦ в органах тварин, оцінити можливість корекції порушених під впливом гіпер- та гіпотиреозу процесів обміну ГЦ за допомогою вітамінів $\mathrm{B}_{6}, \mathrm{~B}_{9}, \mathrm{~B}_{12}$ i бетаїну.

МЕТОДИ ДОСЛІДЖЕННЯ. Для дослідЖень використано 110 безпородних щурів-самців масою 150-180 г, яких утримували на стандартному раціоні. Усіх тварин поділили на 11 груп: 1-ша - інтактні щури (інтрагастрально вводили розчин 1 \% крохмалю); 2-га - тварини з гіпертиреозом, яким щоденно протягом 21-го дня вводили інтрагастрально L-тироксин (200 мкг/добу на 1 кг маси); 3-тя - щури з гіпертиреозом, яким щоденно вводили піридоксин (10 мг/кг/добу); 4-та - тварини з гіпертиреозом, яким щоденно вводили бетаїн (20 мг/кг/добу); 5-та - щури 3 гіпертиреозом, яким щоденно вводили фолієву кислоту (2 мг/кг/добу) та ціанокобаламін (0,2 мг/кг/добу); 6-та-тварини з гіпертиреозом, яким щоденно вводили фолієву кислоту, ціанокобаламін, піридоксин і бетаїн; 7-ма - щури 3 гіпотиреозом, яким щоденно протягом 21-го дня вводили мерказоліл (10 мг/добу на 1 кг маси); 8-ма - тварини з гіпотиреозом, яким щоденно вводили піридоксин (10 мг/кг/добу); 9-та щури з гіпотиреозом, яким щоденно вводили бетаїн (20 мг/кг/добу); 10-та - тварини з гіпотиреозом, яким щоденно вводили фролієву кислоту (2 мг/кг/добу) та ціанокобаламін (0,2 мг/кг/добу); 11-та - щури з гіпотиреозом, яким щоденно вводили комбінацію фолієвої кислоти, ціанокобаламіну, піридоксину і бетаїну.
3 дослідів тварин виводили на 22-й день методом цервікальної дислокації. Для дослідів використовували сироватку крові, тканини печінки, нирок та мозку. Експериментальні дослідження було проведено з дотриманням вимог гуманного ставлення до піддослідних тварин, регламентованих Законом України "Про захист тварин від жорстокого поводження" № 3447-IV від 21.02.2006 р. та Європейською конвенцією про захист хребетних тварин, що використовуються для дослідних та інших наукових цілей (Страсбург, 18.03.1986р.). Печінку та нирки перфузували холодним 1,15 \% розчином калію хлориду і гомогенізували при 3000 об./хв у середовищі 1,15\% калію хлориду (співвідношення 1:3). Гомогенати центрифругували впродовж 30 хв при $1500 \mathrm{~g}$ та $+4^{\circ} \mathrm{C}$. У печінці та нирках визначали цистатіонінсинтазну активність цистатіонін$\beta$-синтази (КФ 4.2.1.22) і цистатіоніназну активність цистатіонін-ү-ліази (КФ 4.4.1.1) [5, 6]. Мозок перфузували холодним 1,15 \% розчином калію хлориду і гомогенізували при 3000 об./хв у середовищі 1,15 \% калію хлориду у співвідношенні 1:4 (маса/об'єм). У мозку визначали цистатіоніназну активність ЦБС [6]. Рівень загального цистеїну визначали за реакцією з нінгідриновим реактивом у кислому середовищі після переведення цистину в цистеїн під впливом дитіотреітолу [7]. В сироватці крові визначали загальний вміст ГЦ імунодерментним методом з використанням набору фрірми "Axis-Shield" (Велика Британія). Результати виражали як середнє \pm SEM з 8-10 експериментів. Зміни $p<0,05$ розглядали як статистично достовірні. Статистичний аналіз виконували, використовуючи стандартні статистичні програми і t-критерій Стьюдента.

РЕЗУЛЬТАТИЙ ОБГОВОРЕННЯ. У Таблиці 1 наведено дані, які відображають результати досліджень впливу L-тироксину на реакції транссульфрування ГЦ. У цьому шляху ГЦ спочатку під впливом ензиму ЦБС конденсується із серином з утворенням цистатіоніну, а потім останній розщеплюється ЦГЛ до цистеїну, $\alpha$-кетобутирату й аміаку. Обидві реакції є піридоксальсоосфратозалежними, тобто вимагають забезпеченості вітаміном $\mathrm{B}_{6}$.

У печінці щурів, яким вводили L-тироксин, цистатіонінсинтазна активність ЦБС підвищувалася на 35 \% порівняно з контрольною групою тварин. Водночас у нирках щурів, яким вводили тироксин, активність цього ензиму не зазнавала достовірних змін. У мозку щурів активність ЦБС була на 82 \% вищою порівняно з інтактними тваринами. E. Turbat-Herrera та ін. (2018) [8] встановили, що рівень експресії протеїну ЦБС зростає при фолікулярних аденомах щитоподіб- 
Таблиця 1 - Активність (нмоль/хв-мг протеїну) ензимів синтезу цистеїну в печінці, нирках та мозку щурів з моделлю гіпертиреозу при застосуванні фролієвої кислоти,

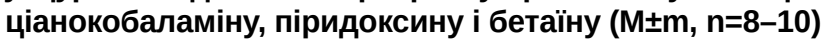

\begin{tabular}{|c|c|c|c|c|c|c|c|}
\hline \multirow[b]{3}{*}{ Ензим } & \multirow[b]{3}{*}{$\begin{array}{c}\text { Об'єкт } \\
\text { дослі- } \\
\text { дження }\end{array}$} & \multicolumn{6}{|c|}{ Група тварин } \\
\hline & & \multirow[b]{2}{*}{ інтактні } & \multicolumn{5}{|c|}{ тварини з гіпертиреозом (21 доба) } \\
\hline & & & L-тироксин & $\begin{array}{c}\mathrm{L}-\mathrm{Tи}- \\
\text { роксин+B }\end{array}$ & $\begin{array}{c}\text { L-ти- } \\
\text { роксин+ } \\
\text { бетаїн }\end{array}$ & $\begin{array}{c}\text { L-ти- } \\
\text { роксин+ } \\
\mathrm{B}_{9}+\mathrm{B}_{12}\end{array}$ & \begin{tabular}{|c} 
L-ти- \\
роксин+ \\
$\mathrm{B}_{6}+\mathrm{B}_{9}+\mathrm{B}_{12}+$ \\
бетаїн
\end{tabular} \\
\hline \multirow{3}{*}{$\begin{array}{l}\text { Цистатіонінсин- } \\
\text { тазна активність } \\
\text { ЦБС }\end{array}$} & Печінка & $12,10 \pm 0,65$ & $16,38 \pm 1,21^{*}$ & $18,70 \pm 1,31^{*}$ & $16,46 \pm 1,40^{*}$ & $16,61 \pm 1,52^{*}$ & $18,94 \pm 1,28^{*}$ \\
\hline & Нирки & $16,82 \pm 1,33$ & $17,65 \pm 1,28$ & $21,18 \pm 1,45^{\star}$ & $18,53 \pm 1,32$ & $18,36 \pm 1,42$ & $22,59 \pm 1,52^{*}$ \\
\hline & Мозок & $6,02 \pm 0,59$ & $10,98 \pm 0,78^{*}$ & $13,18 \pm 1,05^{\star}$ & $11,53 \pm 0,89 *$ & $11,31 \pm 0,76^{*}$ & $13,62 \pm 1,18^{*}$ \\
\hline \multirow{2}{*}{$\begin{array}{l}\text { Цистатіоніназна } \\
\text { активність ЦГл }\end{array}$} & Печінка & $16,19 \pm 1,06$ & $17,61 \pm 1,30$ & $21,13 \pm 1,05$ & $18,31 \pm 1,41$ & $17,96 \pm 1,38$ & $22,36 \pm 1,15^{*}$ \\
\hline & Нирки & $13,64 \pm 0,98$ & $16,85 \pm 1,28$ & $20,39 \pm 1,48^{*}$ & $17,69 \pm 1,32$ & $17,86 \pm 1,40$ & $20,56 \pm 1,52^{\star}$ \\
\hline
\end{tabular}

Примітка. Тут і в таблиці 2 зміни достовірні: * - порівняно з інтактними тваринами; ${ }^{\$}$ - порівняно 3 групою тварин, яким вводили мерказоліл.

ної залози, а також при фролікулярних, сосочкових, анапластичних та медулярних карциномах щитоподібної залози, при цьому підвищена експресія протеїну корелює з такими параметрами, як стадія пухлини, анаплазія, наявність метастазів і стійкість до хіміотерапії. Z. Fengjiao та ін. (2018) [9] з'ясували, що ступінь експресії ЦБС у мозку щурів залежить від рівня тиреотропного гормону і тироксину. Було встановлено, що лептин стимулює ядерну транслокацію протеїну FOXO3a, збільшує активність зв'язування FOXOЗа до двох сайтів промотора ЦБС і посилює експресію ЦБС. Автори дійшли висновку, що зростання рівня в гіпоталамусі ЦБС/ $\mathrm{H}_{2} \mathrm{~S}$ викликає зменшення жирової маси та інсулінорезистентності й може бути мішенню для методів профілактики або лікування метаболічних захворювань.

У печінці та нирках щурів з гіпертиреозом не відбувалося достовірних змін цистатіоназної активності ЦГЛ.

Піридоксин спричиняв підвищення цистатіонінсинтазної активності ЦБС у печінці тварин з гіпертиреозом на 55 \% порівняно з контрольною групою щурів, у нирках активність цього ензиму була на 26 \% більшою, ніж у контрольній групі. На цистатіоніназну активність ЦГЛ піридоксин справив достовірний (на 49 \%) ефрект лише в нирках. Бетаїн також викликав достовірне зростання активності ЦБС у тварин з гіпертиреозом: у нирках - на 36 \%, у мозку тварин - на $92 \%$ проти контролю. Використання комбінації препаратів $\mathrm{B}_{9}$ та $\mathrm{B}_{12}$ призводило до достовірних змін активності ЦБС: у печінці-на $37 \%$, у нирках - на 88 \%. Комбінація вітамінів $\mathrm{B}_{6}, \mathrm{~B}_{9}, \mathrm{~B}_{12}$ і бетаїну викликала підвищення активності ЦБС: у тканині печінки - на 57 \%, у нирках - на 31 \%, у тканині мозку - на 126 \% порівняно з контролем. Застосування всіх середників також спричиняло збільшення активності ЦГЛ: у печінці - на 38 \%, у нирках - на $51 \%$.

Введення піддослідним тваринам мерказолілу (табл. 2) призводило до зменшення швидкості реакцій транссульфрування ГЦ. У печінці, нирках та мозку щурів з гіпотиреозом цистатіонінсинтазна активність ЦБС достовірно знижувалася - відповідно, на 30, 37 і 48 \% порівняно 3 контролем. Подібну тенденцію з цистатіоніназною активністю ЦГЛ спостерігали лише в нирках - зменшення на 27 \% проти контролю.

Таблиця 2 - Активність (нмоль/хв-мг протеїну) ензимів синтезу цистеїну в печінці, нирках та мозку щурів з моделлю гіпотиреозу при застосуванні фолієвої кислоти,

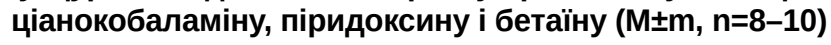

\begin{tabular}{|c|c|c|c|c|c|c|c|}
\hline \multirow[b]{3}{*}{ Ензим } & \multirow{3}{*}{$\begin{array}{l}\text { Об'єкт } \\
\text { дослі- } \\
\text { дження }\end{array}$} & \multicolumn{6}{|c|}{ Група тварин } \\
\hline & & \multirow[b]{2}{*}{ інтактні } & \multicolumn{5}{|c|}{ тварини з гіпотиреозом (21 доба) } \\
\hline & & & мерказоліл & $\begin{array}{l}\text { мерказо- } \\
\text { ліл+B } 6\end{array}$ & $\begin{array}{c}\text { мерказо- } \\
\text { ліл+бетаїн }\end{array}$ & $\begin{array}{c}\text { мерказо- } \\
\text { ліл+B }+\mathrm{B}_{12}\end{array}$ & $\begin{array}{c}\text { мерказо- } \\
\text { ліл+B }+\mathrm{B}_{9}+ \\
\mathrm{B}_{12}+\text { бетаїн }\end{array}$ \\
\hline \multirow{3}{*}{$\begin{array}{l}\text { Цистатіонінсин- } \\
\text { тазна активність } \\
\text { ЦБС }\end{array}$} & Печінка & $12,10 \pm 0,65$ & $8,51 \pm 0,46^{\star}$ & $11,66 \pm 0,68^{\$}$ & $9,36 \pm 0,54^{*}$ & $9,19 \pm 0,49$ & $11,83 \pm 0,75^{\$}$ \\
\hline & Нирки & $16,82 \pm 1,33$ & $10,54 \pm 0,86^{*}$ & $13,49 \pm 1,24$ & $11,38 \pm 0,69 *$ & $11,17 \pm 0,62^{*}$ & $13,60 \pm 1,28$ \\
\hline & Мозок & $6,02 \pm 0,59$ & $3,16 \pm 0,18^{\star}$ & $3,95 \pm 0,18^{\star \$}$ & $3,38 \pm 0,21^{*}$ & $3,41 \pm 0,25^{\star}$ & $4,01 \pm 0,23^{\star \$}$ \\
\hline \multirow{2}{*}{$\begin{array}{l}\text { Цистатіоніназна } \\
\text { активність ЦГл }\end{array}$} & Печінка & $16,19 \pm 1,06$ & $11,60 \pm 1,06$ & $14,27 \pm 1,24$ & $12,18 \pm 1,15$ & $12,30 \pm 1,18$ & $14,15 \pm 1,28$ \\
\hline & Нирки & $13,64 \pm 0,98$ & $10,02 \pm 0,60 *$ & $12,32 \pm 0,75$ & $10,42 \pm 0,71^{*}$ & $10,55 \pm 0,78$ & $12,63 \pm 0,65^{\$}$ \\
\hline
\end{tabular}


Ми встановили, що піридоксин запобігав пригніченню транссульфрування ГЦ при гіпотиреозі та призводив до зростання в печінці активності ЦБС на 37 \% порівняно з групою тварин, В яких викликали гіпотиреоз. У мозку щурів, у яких моделювали стан гіпотиреозу, активність ЦБС при застосуванні піридоксину була на 34 \% нижчою порівняно з групою тварин, яким корекції не проводили. Використання піридоксину в щурів 3 гіпотиреозом достовірного ефекту на активність ЦГЛ у печінці та нирках не справило. Бетаїн не спричиняв позитивних змін у реакціях транссульсування ГЦ в органах тварин при гіпотиреозі. Застосування комбінації препаратів $\mathrm{B}_{9}$ та $\mathrm{B}_{12}$ викликало достовірні зміни активності лише ЦБС у печінці та нирках, яка була нижчою на 24 і $43 \%$ порівняно $з$ групою щурів, яким корекції не проводили. Комбінація вітамінів групи В і бетаїну зумовлювала зростання активності ЦБС у печінці на $39 \%$, водночас у тканині мозку спостерігали протилежні зміни: зменшення ії на 33 \% проти контрольної групи тварин та на $27 \%$ порівняно зі щурами з гіпотиреозом. При використанні комбінації вітамінів $\mathrm{B}_{6}, \mathrm{~B}_{9}, \mathrm{~B}_{12} \mathrm{i}$ бетаїну активність ЦГЛ у тканині нирок була на 26 \% вищою, ніж у тварин, в яких моделювали гіпотиреоз.

Ми також з'ясували, що гіпертиреоз знижував рівень ГЦ на $23 \%$ порівняно 3 групою тварин, яким корекції не проводили $(3(8,53 \pm 0,41)$ до $(6,53 \pm 0,48)$ мкмоль/л). Вітамін В $_{6}$ У тварин 3 гіпертиреозом призводив до ще більшого його зменшення (до $(5,80 \pm 0,46)$ мкмоль/л). При застосуванні бетаїну за гіпертиреозу рівень ГЦ становив $(6,14 \pm 0,51)$ мкмоль/л, а при використанні 3 метою корекції вітамінів $\mathrm{B}_{9}$ та $\mathrm{B}_{12}-$ $(6,06 \pm 0,47)$ мкмоль/л.

Можна передбачити, що застосування всіх середників призведе до активізації утилізації ГЦ, як шляхом його реметилювання до метіоніну, так і шляхом його транссульсрування до цистеїну. Використання комбінації вітамінів $\mathrm{B}_{6}, \mathrm{~B}_{9}, \mathrm{~B}_{12} \mathrm{i}$

\section{СПИСОК ЛІТЕРАТУРИ}

1. Homocysteine and homocysteine-related compounds: an overview of the roles in the pathology of the cardiovascular and nervous systems / D. Djuric, V. Jakovljevic, V. Zivkovic [et al.] // Can. J. Physiol. Pharmacol. - 2018. - 96 (10). - P. 991-1003.

2. Disturbed homocysteine metabolism is associated with cancer / H. Tauheed, A. Reetika, B. Aniket Kumar [et al.] // Exp. Mol. Med. - 2019. - 51 (2). - P. 1-13.

3. Jakubowski H. Homocysteine modification in protein structure / $\mathrm{H}$. Jakubowski // Function and Human Disease. Physiol Rev. - 2019. - 99 (1). - P. 555-604. бетаїну у тварин, яким вводили L-тироксин, викликало достовірне зниження рівня ГЦ (до $(5,85 \pm 0,38)$ мкмоль/л), що було на $31 \%$ менше, ніж у контрольній групі.

Мерказоліл спричиняв зростання рівня ГЦ на $160 \%$ (3 (8,53 $\pm 0,41)$ до $(22,21 \pm 1,50)$ мкмоль/л). При введенні тваринам з гіпотиреозом піридоксину він знижувався на $25 \%(3(22,21 \pm 1,50)$ до $(16,57 \pm 1,15)$ мкмоль/л). У роботі [10] було встановлено подібні результати. Автори припустили, що виникнення дефіциту вітаміну $\mathrm{B}_{6}$ тісно пов'язано з розвитком гіпоталамічного типу гіпотиреозу. Використання комбінації препаратів $\mathrm{B}_{9}$ та $\mathrm{B}_{12}$ у тварин з гіпотиреозом викликало підвищення рівня ГЦ лише на $60 \%(3(8,53 \pm 0,41)$ до $(14,08 \pm 1,20)$ мкмоль/л) порівняно з інтактними тваринами. M. Gołyński та iн. (2017) [11] досліджували взаємозв'язок між концентрацією ГЦ у сироватці крові, рівнем фолієвої кислоти та гормонами щитоподібної залози. Автори дійшли висновку, що гіпотиреоз спричиняє гіпергомоцистеїнемію, а супутнє зниження рівня фоллієвої кислоти при гіпотиреозі може бути наслідком її розвитку.

Тривалий гіпертиреоз не призводив до змін рівня цистеїну в крові щурів. Препарати, які ми обрали, чи їх комбінація не впливали на рівень цистеїну в крові тварин з гіпертиреозом. На відміну від гіпертиреозу, гіпотиреоз, змодельований шляхом введення мерказолілу, викликав підвищення рівня цистеїну в крові щурів на $40 \%$ (3 $(111,50 \pm 6,61)$ у контрольній групі до $(156,30 \pm 8,74)$ мкмоль/л). Досліджувані препарати суттєво не впливали на вміст цистеїну в крові тварин з гіпотиреозом.

ВИСНОВКИ. Тривалі гіпер- та гіпотиреоз викликають дисбаланс шляху транссульфрування ГЦ. Комбінація піридоксину, фолієвої кислоти, ціанокобаламіну і бетаїну є ефективним методом корекції транссульфруразного шляху та, як наслідок, вмісту ГЦ у плазмі крові при диссрункції щитоподібної залози. 
mones and amino acids in vivo / K. Heinonen // Biochem. J. - 1973. - 136, No. 4. - P. 1011-10155.

7. Gaitonde M. K. A spectrophotometric method for the direct determination of cysteine in the presence of other naturally occurring amino acids / M. K. Gaitonde // Biochem. J. - 1967. - 104, No. 2. - P. 627-633.

8. Cystathione $\beta$-synthase is increased in thyroid malignancies / E. A. Turbat-Herrera, M. J. Kilpatrick, J. Chen [et al.] // Anticancer. Res. - 2018. - 38 (11). P. 6085-6090.

9. Cystathionine beta synthase-hydrogen sulfide system in paraventricular nucleus reduced high fatty diet induced obesity and insulin resistance by brain-adipose axis / Z. Fengjiao, H. Jingnan, L. Haocheng [et al.] // Biochimica et Biophysica Acta (BBA) - Molecular Basis of Disease. - 2018. - 1864 (10). - P. 3281-3291.

10. Krishnamurti Dakshinamurti S. Vitamin $B_{6}$ : Effects of deficiency, and metabolic and therapeutic functions / Krishnamurti S. Dakshinamurti, M. Dakshinamurti, P. Czubryt. - Handbook of Famine, Starvation, and Nutrient Deprivation. - 2017. - P. 1-23.

11. Relationship between total homocysteine, folic acid, and thyroid hormones in hypothyroid dogs / M. Gołyński, K. Lutnicki, W. Krumrych [et al.] // J. Vet. Intern. Med. - 2017. - 31 (5). - P. 1403-1405.

\section{REFERENCES}

1. Djuric, D., Jakovljevic, V., Zivkovic, V., \& Srejovic, I. (2018). Homocysteine and homocysteine-related compounds: an overview of the roles in the pathology of the cardiovascular and nervous systems. Can. J. Physiol. Pharmacol., 96 (10), 991-1003.

2. Tauheed, H., Reetika, A., Aniket Kumar, B., Reshmee, B., Gurumayum Suraj, S., \& Laishram Rajendrakumar, S. (2019). Disturbed homocysteine metabolism is associated with cancer. Exp. Mol. Med., 51 (2), 1-13.

3. Jakubowski, H. (2019). Homocysteine modification in protein structure. Function and human disease. Physiol. Rev., 99 (1), 555-604.

4. Nechiporuk, V., Zaichko, N., Korda, M., Melnyk, A., \& Koloshko, O. (2017). Sulphur-containing amino acids metabolism in experimental hyper- and hypothyroidism in rats. Georgian Medical News, Tbilisi State Medical University, 10 (271), 96-102.

5. Goldstein, J.L., Campbell, B.K., \& Gartler, S.M. (1972). Cystathionine synthase activity in human lymphocytes: induction by phytohemagglutinin. J. Clin. Invest., 51 (4), 1034-1037.

6. Heinonen, K. (1973). Studies on cystathionase activity in rat liver and brain during development. Effects of hormones and amino acids in vivo. Biochem. J., 136 (4), 1011-10155.
7. Gaitonde, M.K. (1967). A spectrophotometric method for the direct determination of cysteine in the presence of other naturally occurring amino acids. Biochem. J., 104 (2), 627-633.

8. Elba Turbat-Herrera, A., Matthew Kilpatrick, J., Chen Jie, Andrew Meram, T., Cotelingam, J., Ghali, G., Christopher Kevil, G., Coppola, D., \& Rodney Shackelford, E. (2018). Cystathione $\beta$-Synthase is increased in thyroid malignancies. Anticancer Res., 38 (11), 60856090.

9. Fengjiao, Z., Jingnan, H., Haocheng, L., Changting, C., Jichun, Y., Qinghua, C., Jun C., Yong, Z., Chaoshu, T., Guoheng, X., \& Bin, G. (2018). Cystathionine beta synthase-hydrogen sulfide system in paraventricular nucleus reduced high fatty diet induced obesity and insulin resistance by brain-adipose axis. Biochimica et Biophysica Acta (BBA) Molecular Basis of Disease, 1864 (10), 3281-3291.

10. Krishnamurti S. Dakshinamurti, M. Dakshinamurti, \& P. Czubryt (2017). Vitamin B $B_{6}$ : Effects of deficiency, and metabolic and therapeutic functions. Handbook of Famine, Starvation, and Nutrient Deprivation.

11. Gołyński, M., Lutnicki, K., Krumrych, W., Szczepanik, M., Gołyńska, M., Wilkołek, P., Adamek, Ł., Sitkowski, Ł., \& Kurek, Ł. (2017). Relationship between total homocysteine, folic acid, and thyroid hormones in hypothyroid dogs. J. Vet. Intern. Med., 31 (5), 1403-1405.

В. М. Нечипорук ${ }^{1}$, М. М. Корда ${ }^{2}$ ВИННИЦКИЙ НАЦИОНАЛЬНЫЙ МЕДИЦИНСКИЙ УНИВЕРСИТЕТ ИМ. Н. И. ПИРОГОВА ТЕРНОПОЛЬСКИЙ НАЦИОНАЛЬНЫЙ МЕДИЦИНСКИЙ УНИВЕРСИТЕТ ИМЕНИ И. Я. ГОРБАЧЕВСКОГО МОЗ УКРАИНЫ ${ }^{2}$

\section{КОРРЕКЦИЯ ВИТАМИНАМИ ГРУППЫ В НАРУШЕНИЙ ТРАНССУЛЬФУРАЗНОГО ПУТИ УТИЛИЗАЦИИ ГОМОЦИСТЕИНА ПРИ ГИПЕР- И ГИПОФУНКЦИИ ЩИТОВИДНОЙ ЖЕЛЕЗЫ}

\section{Резюме}

Вступление. Диссункция щитовидной железы - фрактор развития многих сердечно-сосудистых заболеваний, в то же время гипергомоцистеинемия также является хорошо известным фрактором развития патологий сердечно-сосудистой системы. Установлено, что экспериментальный гипертиреоз 
вызывает уменьшение уровня гомоцистеина (ГЦ) в крови, одновременно гипотиреоз приводит к противоположным изменениям в обмене серосодержащих аминокислот, в частности, повышается содержание ГЦ в крови, снижается уровень $\mathrm{H}_{2} \mathrm{~S}$ и возрастает уровень цистеина, что является следствием изменений активности энзимов метаболизма метионина.

Цель исследования - выяснить влияние гормонов щитовидной железы на процессы транссульфрирования ГЦ в органах животных, оценить возможность коррекции нарушенных под влиянием гипер- и гипотиреоза процессов обмена ГЦ с помощью витаминов $B_{6}, B_{9}, B_{12}$ u бетаина.

Методы исследования. Работа выполнена на крысах-самцах, у которых исследовали влияние гипер(L-тироксин, 200 мкг/сутки на 1 кг массы) и гипотиреоза (мерказолил, 10 мг/сутки на 1 кг массы) на реакции транссульфрирования ГЦ в органах животных и коррекцию нарушенных под влиянием L-тироксина и мерказолила процессов обмена ГЦ с помощью витаминов $B_{6}, B_{9}, B_{12}$ и бетаина. B печени и почках определяли цистатионинсинтазную активность цистатионин- $\beta$-синтазы (ЦБС) и цистатиониназную активность цистатионин-у-лиазы (ЦГЛ), в мозге - только активность ЦБС, в крови - содержание ГЦ и цистеина.

Результаты и обсуждение. Гипертиреоз вызывал возрастание цистатионинсинтазной активности ЦБС в печени и мозге. Применение витамина $B_{6}$ у животных с гипертиреозом приводило к еще большему повышению этого показателя. Цистатиониназная активность ЦГЛ при гипертиреозе и использовании витамина $B_{6}$ достоверно возрастала лишь в почках. Бетаин, $B_{9}$ и $B_{12}$ у животных с гипертиреозом вызывали повышение активности ЦБС в мозге и печени. Гипертиреоз снижал уровень ГЦ и не влиял на уровень цистеина. Фолиевая кислота, цианокобаламин, пиридоксин и бетаин, при их введении параллельно с L-тироксином, частично предотвращали уменьшение концентрации ГЦ в крови. Мерказолил подавлял активность энзимов пути транссульфирования по сравнению с интактными животными: ЦБС - в печени и почках, ЦГЛ - в почках. Пиридоксин частично предупреждал снижение активности ЦБС в печени и мозге, бетаин - активности ЦБС в тканях печени, почек и мозга и активности ЦГЛ только в почках. Самой эффрективной оказалась комбинация витаминов группы В и бетаина. Гипотиреоз приводил к повышению содержания в крови ГЦ и цистеина. Витамины $B_{6}, B_{9}$ u $B_{12}$, а также комбинация всех средств вызывали у животных с гипотиреозом снижение уровня ГЦ.

Выводы. Длительные гипер- и гипотиреоз вызывают дисбаланс пути транссульфрирования ГЦ. Фолиевая кислота, цианокобаламин, пиридоксин и бетаин частично предотвращают нарушение процессов метаболизма серосодержащих аминокислот и приводят к снижению уровня ГЦ и цистеина в крови крыс с гипотиреозом.

КЛЮЧЕВЫЕ СЛОВА: гипертиреоз; гипотиреоз; цикл транссульфирования; гомоцистеин; цистеин; витамины $\mathrm{B}_{6}, \mathrm{~B}_{9}, \mathrm{~B}_{12}$; бетаин.

V. M. Nechiporuk ${ }^{1}$, M. M. Korda ${ }^{2}$ M. PYROHOV VINNYTSIA NATIONAL MEDICAL UNIVERSITY ${ }^{1}$ I. HORBACHEVSKY TERNOPIL NATIONAL MEDICAL UNIVERSITY²

\section{CORRECTION BY VITAMINS OF GROUP B IN DISTURBANCES OF HOMOCYSTEIN UTILIZATION IN TRANSCULTURATION PATHWAY IN HYPER- AND HYPOFUNCTIONS OF THE THYROID}

\section{Summary}

Introduction. Thyroid dysfunction is a factor in the development of many cardiovascular diseases, at the same time, hyperhomocysteinemia is also a well-known factor in the development of pathologies of the cardiovascular system. It was found that experimental hyperthyroidism causes a decrease in the level of homocysteine (HCy) in the blood, while hypothyroidism leads to opposite changes in the exchange of sulfur-containing amino acids, in particular, an increase in the HCy content in the blood, a decrease in the level of $\mathrm{H}_{2} \mathrm{~S}$ and an increase in the level of cysteine, which is a consequence of changes in the activity of enzymes metabolism of methionine.

The aim of the study - to elucidate the effect of thyroid hormones on the processes of HCy transsulfuration in animal organs and to assess the possibility of correcting HCy metabolism disturbed under the influence of hyperand hypothyroidism with the help of vitamins $B_{6}, B_{9}, B_{12}$ and betaine.

Research Methods. The work was performed on male rats, in which the effect of hyper- (L-thyroxine, $200 \mu \mathrm{g} /$ day per $1 \mathrm{~kg}$ of body weight) and hypothyroidism (thiamazole, $10 \mathrm{mg} /$ day per $1 \mathrm{~kg}$ of body weight) on the reaction of transsulfuration $\mathrm{HCy}$ in animal organs and disturbed under the influence of $L$-thyroxine and thiamazole the metabolic processes of $\mathrm{HCy}$ with the help of vitamins $B_{6}, B_{9}, B_{12}$ and betaine. In the liver and kidneys, the cystathionine synthase 
activity of cystathionine- $\beta$-synthase (CBS) and the cystathionine-y-lyase (CSE) activity were determined, in the brain - only the activity of CBS, in the blood - the content of HCy and cysteine.

Results and Discussion. Hyperthyroidism caused an increase in the cystathionine synthase activity of CBS in the liver and brain. The use of vitamin $B_{6}$ in animals with hyperthyroidism led to an even greater increase in this indicator. The cystathioninase activity of CSE in hyperthyroidism and the use of $B_{6}$ significantly increased only in the kidneys. Betaine, $B_{9}$ and $B_{12}$ in animals with hyperthyroidism caused an increase in the activity of CSE in the brain and liver. Hyperthyroidism lowers HC levels and does not affect cysteine levels. Folic acid, cyanocobalamin, pyridoxine, and betaine, when administered in parallel with L-thyroxine, partially prevented a decrease in the concentration of $\mathrm{HC}$ in the blood. Thiamazole suppressed the activity of enzymes of the transsulfuration pathway in comparison with intact animals: CSE - in the liver and kidneys, CSE - in the kidneys. Pyridoxine partially prevented a decrease in the activity of CBL in the liver and brain, betaine - the activity of CSE in the tissues of the liver, kidneys and brain, and only in the kidneys of the activity of CSE. The combination of $B$ vitamins and betaine proved to be effective. Hypothyroidism led to increased blood levels of $H C y$ and cysteine. Vitamin $B_{6}, B_{9}$ and $B_{12}$, as well as the combination of all mediators, caused a decrease in the level of HCy in animals with hypothyroidism.

Conclusions. Our results indicate that long-term hyper- and hypothyroidism cause an imbalance in the HCy transsulfuration pathway. Folic acid, cyanocobalamin, pyridoxine and betaine partially prevent the disturbance of the metabolic processes of sulfur-containing amino acids and lead to a decrease in the level of HCy and cysteine in the blood of rats with hypothyroidism.

KEYWORDS: hyperthyroidism; hypothyroidism; transsulfuration cycle; homocysteine; cysteine; vitamins $B_{6}, B_{9}, B_{12}$; betaine.

Отримано 27.08.20

Адреса для листування: В. М. Нечипорук, Вінницький національний медичний університет ім. М. І. Пирогова, вул. Пирогова, 56, Вінниця, 21018, Україна, е-mail: nechiporuk@vnmu.edu.ua. 